\title{
Macroeconomic Effects of Exogenous Oil Price Shock in Nigeria: Persistent or Transitory
}

\author{
Angela Ifeanyi Ukemenam ${ }^{1}$, Babatunde Opadeji ${ }^{2}$, Tuwe Soro Garbobiya ${ }^{2} \&$ Augustine Ujunwa ${ }^{2}$ \\ ${ }^{1}$ Department of Banking and Finance, University of Nigeria, Enugu Campus \\ ${ }^{2}$ Monetary Policy Department, Central Bank of Nigeria, Abuja, Nigeria \\ Correspondence: Augustine Ujunwa, Monetary Policy Department, Central Bank of Nigeria, Abuja, Nigeria. Tel: \\ 234-803-501-0116. E-mail: austinesilver@yahoo.com
}

Received: August 23, 2018

Accepted: September 21, 2018

Online Published: October 20, 2018

doi:10.5539/ijef.v10n11p28

URL: https://doi.org/10.5539/ijef.v10n11p28

\begin{abstract}
This paper examines the macroeconomic effects of exogenous oil price shock in Nigeria. The paper additionally investigates the symmetric effects of oil price shock and the persistence and/or transitory nature of the shock. To achieve these objectives, the Generalised autoregressive conditional heteroskedasticity (GARCH), Component generalised autoregressive conditional heteroskedasticity (CGARCH) and Exponential generalized autoregressive conditional heteroskedasticity $(\mathrm{EGARCH})$ were employed to estimate the various equations. The results showed that oil price volatility has significant positive effect on exchange rate, foreign external reserves, government revenue, and capital importation. The results also revealed symmetric and persistent effect of oil shock in Nigeria. Based on the results, the paper made recommendations for ameliorating and/or insulating Nigeria from the vulnerabilities of oil price shocks.
\end{abstract}

Keywords: exogenous oil shocks, transitory shocks, persistent shocks, macroeconomic variables

\section{Introduction}

Crude oil is one of the fundamental energy sources to the importing and exporting countries. For the exporting countries, it is a major source of foreign exchange earnings and most importantly, the dominant source of revenue for the government. For importing countries, it is an important chemical raw material for multiple uses. This explains the multiplier effects of price shock of crude oil to energy and economic security (Yuan, Liu, \& Huang, 2014). Historical oil shocks are attributed to disruptions of oil flows from oil exporting countries and weakness in demand for oil in the international market.

The earliest oils shocks could be traced to disruptions of oil flows from exporting countries. Specifically, they are traced to episodes such as the Yom Kippur War of October 6, 1973 - when the Organisation of Arab Petroleum Exporting Countries (OAPEC) issued a warning of its intention to cut crude oil production by 5 per cent on October 16, "until Israeli soldiers were completely evacuated from all the Arab territories occupied since the June 1967 war and the legitimate rights of the Palestinian people are restored"; the Iranian revolution in the fall of 1978; Iraq and Iran crisis of September 1980; and Iraq and Kuwait crisis of August 1990 (see Hamilton, 2009). These episodes usually result in significant increase in the prices oil. For instance, oil price increased by 25 per cent during the 1980 crisis and 70 per cent in 1990 crisis (Hamilton, 2009).

The 2007-2008 oil shock has been described as the biggest oil shock on record. The causes of the shock were different from the earlier episodes and could be classified into supply, demand and the role of speculation. One major determinant of the 2007-2008 oil shock was the global financial crisis that lowered economic activities and weakened demand. Similarly global demand for crude oil nose-dived within the period as consumption in the United States was 122,000 barrels below the 2005 level; Europe and Japan dropped 346,000 and 318,000 barrels respectively.

The recent oil price shock (large fall in oil prices) have been attributed to factors such as higher than expected supply (see table 1), weakness in global demand for oil, driven largely by improvements in production technology, particularly the shale technology in the United States, steady rise in production of countries not belonging to Organisation of the Petroleum Exporting Countries (OPEC), the faster than expected recovery of production in some stressed OPEC producers (Iran for instance); OPEC's November 2014 decision to maintain 
production level despite the sharp decline in prices, which clearly shows that the trend might not abate soon unlike other episodes.

Brent oil price declined by 24 per cent to a four-year low of USD81 as at November 11, 2014. The price of Brent fell from USD114.91 on January 31 to USD102.12 on May 31, and stood at USD57.8 and 67.6 on March 31, 2015. Chart 1 shows the downward trend in Brent and WTI and OPEC basket prices during March 31, 2014 and May 22, 2015. The price of WTI increased from USD97.49 on January 31, 2013 to USD102.49 but declined to USD48.24 on January 30, 2015, which represents 60 per cent year - to - date fall in price per barrel. Similarly, the basket of OPEC prices decline from USD109.28 on January 30, 2013 to USD105.38 on February 28, 2014, and declined further to USD44.38 on January 30, 2015, representing 59 per cent year-to-date reduction in price.

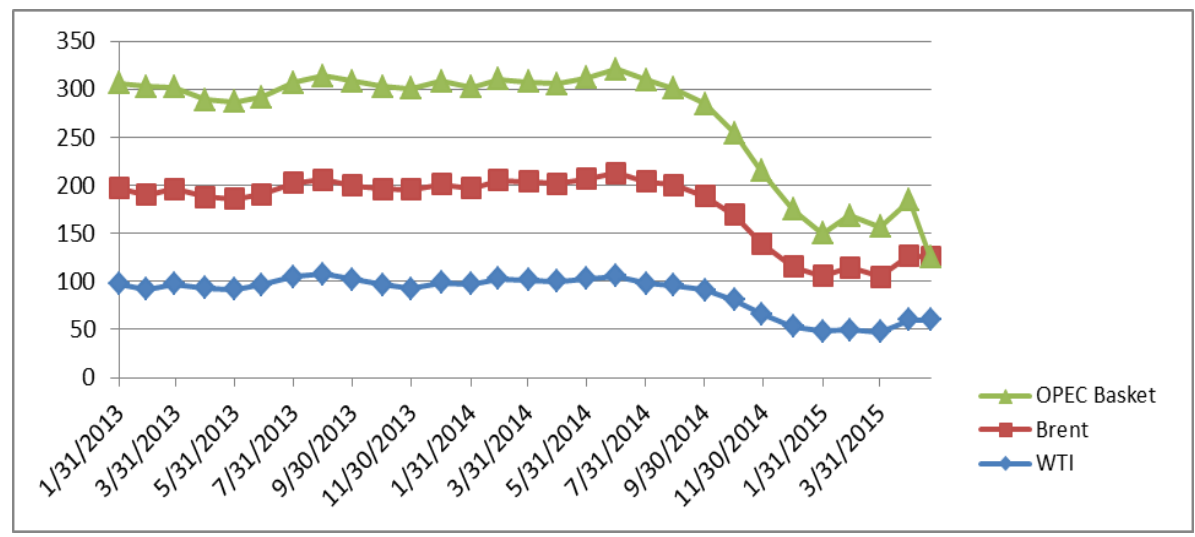

Figure 1. Price of Brent, WTI and OPEC basket

Source: Bloomberg.

The recent shock in crude oil prices which started in July 2014 has adversely affected Nigeria, especially in the areas of foreign reserves, currencies crisis, declining government revenue, and most importantly, threat to its legitimacy in terms of ability to meet financial obligations as at when due. This has also generated policy prescriptions among scholars and policy makers in terms the need to diversify the economy, reducing the size of government, reduction in cost of governance, removal of fuel subsidy, among others. These recommendations, however, may not have been influenced by any empirical study.

Similarly, recent empirical studies along this line focused more on developed and developing economies that are majorly oil importers. For instance, Nazlioglu, Soytas, and Gupta (2015) examined volatility transmission between oil prices and financial stress in the United States financial system; Yuan, Liu, and Huang (2014) analysed dynamics of frequent price shocks crude oil markets in order to identify the temporal properties of price shock sequence; An, Jin, and Ren (2014) examined the asymmetric effects of oil price shock on the economic activities of United states using the non-linear Factor-Augmented Vector Autogressive (FAVAR) model; and Valadkhani (2014) investigated the dynamic effects rising oil prices on consumer energy prices in Canada and the United States.

The objectives of this are paper in three folds. First is to determine whether crude oil price shock is persistent or transitory. When agents believe that the effects of shocks will be permanent, shocks feed into their expectations, and the persistence of shock is thus large. In the same vein, when agents believe that the effects of shocks are only temporary, prices quickly return to its initial position. Knowing whether shocks are permanent or transitory and what determines the magnitude of the effects is important in formulating policy. Recent studies, are the works of Narayan and Liu (2014) that investigated whether price shocks for ten commodities (gold, silver, platinum, copper, aluminum, iron ore, lead, nickel, tin and zinc) are persistent or transitory; Shahbaz, Tiwari, Ozturk, and Farooq (2013) that investigated the unit root properties of electricity consumption of 67 developed and developing countries; and Zhang and Li (2014) that investigated whether the behaviour of hikes in oil-equity market in UK, US, Germany and the five BRICS member countries (Brazil, Russia, India, China and South Africa) are transitory or permanent using asymmetric dynamic conditional correlation model. Thus, this study fills the dearth of empirical study along this line using Nigerian data.

Second is to investigate whether the macroeconomic effects of oil price shocks (positive shock and negative shock) is symmetric. This is extremely important, especially in determining the quantity of fiscal or 
countercyclical buffers to build in good time (economic boom) which will serve as buffer in bad times (economic burst). Economist considers variability of oil prices as the major source of macroeconomic fluctuations (see An, Jin, \& Ren, 2014; Jin, 2015; Ibrahim \& Ahmed, 2014; and Allegret, Mignon, \& Sallenave, 2015). Most of these studies are from oil importing and developed economies perspective, which model increasing oil prices as bad news or negative shocks while decreasing oil prices as goods or positive oil shocks, because of the adverse effects of increasing oil prices on such economies. This paper also fills another important research gap by using is oil-exporting country perspective. That is, increasing oil price is the positive shock while declining oil price is negative shocks. The results of this objective influence policy recommendations on the direction of building fiscal buffers during positive shocks.

The third of objective of the paper is to empirically estimate the effect of oil price volatility on four fundamental macroeconomic variables (total government revenue, capital importation, exchange rate and foreign exchange reserves) in Nigeria. The paper therefore adds to literature as well as methodology. Apart from attempting establish the symmetry or asymmetry effects of positive and negative oil price shocks from oil importing country perspective, which is lacking, the macroeconomic importance of oil price uncertainty, that is whether it is transitory or permanent has largely been absent, especially for oil exporting countries like Nigeria. The rest of the paper is structured as follows. Section 2 reviews the related literature; section 3 details the empirical methodology; section 4 presents the results; section 5 presents the policy implications that emanates from the findings; while section 6 concludes the paper.

\section{Review of Related Literature}

External shock is any episode that exogenously determined but shifts the economy temporarily or permanently from its equilibrium position through multiple transmission mechanisms such as trade channel, financial channel, integration of international market channel, and investment channel, among others. External shocks has been exacerbated due to the effects of globalization and improvements in information communication technology, which eliminated some trade barriers, increased economic interconnectedness, and accelerated the spread of economic risk across national boundaries (Cunado \& Perez de Gracia, 2005, 2003).

The drastic economies changes could be positive - economic boom and improved welfare - or negative distressed economy and declined welfare (Canova, 2005). The controversy on external shocks and internal shocks, which accounts for higher variability or fluctuation in out is still inconclusive. For instance, Raddatz (2007) used the VAR approach to estimate the impact of external shocks on output volatility. The result showed that external shocks could only explain a small fraction of output variance, while internal shocks are the major sources of fluctuations. The external shocks considered in the study are terms-of-trade shocks, natural disasters, changes in the state of international economy, fluctuations in aid flows, and changes in international interest rates. In contrast, Jimenez-Rodriguez and Sanchez (2005) and Lilien (1982) used the dispersion hypothesis to demonstrate the negative impact of external shocks on macroeconomic variables. In their view, external shocks such as aid volatility, international conditions, natural disaster and terms-of-trade fluctuations are blamed for macroeconomic fluctuations. Similarly, multilateral institutions such as World Bank (2004), UNCTAD (2002) and IMF (2003) noted that exogenous shocks stymie economic growth. Specifically, they argued that exogenous "shocks... can have a significant negative impact on developing countries' growth, macroeconomic stability, debt sustainability and poverty", and "low-income countries are particularly vulnerable to natural disasters, terms-of-trade shocks, and other adverse shocks", and that the level volatility in world commodity prices are an important influence on economic growth and the incidence of poverty in less developed countries".

In the opinion of 'exogenous shocks causing negative growth theorists', since the events are unpredictable, it could threaten large-scale private sector defaults, trigger distressed assets sales, high bank insolvency, depletion of external reserve, currency crisis and loss of market confidence. A classic example was the 2007/2008 global financial crises that originated in United States, but ravaged the entire architecture of the global financial system.

There is a consensus on the sources of external shock which include natural disasters, energy costs, commodity prices, geopolitical crisis, famine, war, economic policies and market dynamics, fluctuations in aid flows, among others. The severe external shocks hitting the world economies could be traced to financial and productive integrations between various countries and regions following the formation of blocs since the 1970s. The increasing economic interdependence/interrelatedness of national economies across the world through a rapid increase in cross-border movement of goods, service, technology, and capital as a result of globalization is associated with risks broadly classified into economic risk, social risk, environmental risk, technological risk, geopolitical risk and regional risk (Kilian, 2008; Jimenez-Rodriguez \& Sanchez, 2005; and Mehara, 2006).

The effects of external shocks at regional and country-level have been extensively documented in the empirical 
literature. These studies focus predominantly on the effect of increasing oil prices on oil-importing developed economies and the transmission channels. Literature on the impact of declining oil prices on oil-exporting countries, especially, developing economies appears scant. Literature that clarifies our understanding of the impact of declining oil prices on oil-exporting countries such as Nigeria is very important, since empirical studies that reconcile theory with practical reality is lacking.

The effects of oil shocks on macroeconomic variables had received serious consideration in the United States. According to Blanchard (2009), the 1970s oil shocks resulted in increase in inflation and decrease in output. However, the 2000s and 2007 larger increases in the price oil resulted in milder movements in inflation and output. The milder movements in 2000s and 2007 were attributed to two changes in the structure of the economy that have moderated or modified the transmission mechanism of the oil shock such as 'vanishing wage indexation and an improvement in the credibility of monetary policy'. Jimenez-Rodriguez and Sanchez (2005) used Vector autoregressive (VAR) analysis to empirically investigate the effect of oil shocks on the real economic activity of industrialized OECD countries (G-7, Norway and Euro Area). They found significant interaction between oil prices and macroeconomic variables. There was evidence of a non-linear impact of oil prices on real GDP as oil price increases had larger impact on real GDP growth than oil price declines. Increase in oil price was largely found to have a negative impact on economic activity among oil importing countries.

Dibooglu and Aleisa (2004) investigated the sources of macroeconomic fluctuations in Saudi Arabia using structural vector auto regression methods with emphasis on oil prices and changes in terms of trade, while controlling for supply, balance of payments, aggregate demand, and monetary shocks. Their findings are two folds. First, the price level, real exchange rate, and to a lesser extent output were vulnerable to terms of trade shocks. Second, terms of trade was driven by output, trade balance, and aggregate demand shocks.

Bhattachary and Kar (2009) developed a "macro-modelling framework that allows for evaluating the impact of two domestic shocks (rainfall shortfall and fiscal profligacy) and three external shocks (oil price hike, world trade shock and capital flow shock) that affect Indian economy through various channels". Their results show oil price hike, "the capital flow shock and fiscal profligacy show strong pervasiveness, the rainfall shock is moderately pervasive, while the economy is much more resilient to the world trade shock in the long run".

Kose and Riezman (2001) constructed a calibrated stochastic, dynamic multi-sector equilibrium model, to investigate the effect of external shocks on the African economy. The study used trade shocks modeled as fluctuations in the prices of imported capital goods, exported primary commodities and intermediate inputs; and financial shock, modeled as fluctuations in the world real interest rate. Sectoral productivity was used to capture domestic factors in generating macroeconomic fluctuations. Their results indicated that while trade shocks account for roughly 45 per cent of fluctuations in aggregate output, financial shocks play only a minor role. Additionally, they found that adverse trade shocks induce prolonged recessions since they induce a significant decrease in aggregate investment.

Ncube, Ndou, and Gumata (2012) investigated the impact of the 2007/2008 global financial shock on the South African economy using structural VAR models. The result showed that the financial shock led to Rand appreciation, bond yield decline, weaker consumer inflation, and decline in monetary aggregates and real interest rates in South Africa, despite weak trade channel evidence. Sosa and Adler (2012) examined the impact of shocks stemming from Brazil to other Latin America economies using Vector Auto Regression. They used descriptive statistics to show that trade linkages with Brazil are significant for Argentina, Bolivia, Chile, Paraguay, and Uruguay, but weak for the other countries. The econometric estimation also showed countries with significant trade linkages are vulnerable to output shocks from Brazil compared to other countries with less trade linkages. Canova (2005) studied external shocks from the United States transmits to eight Latin American countries, using individual country and average effects posterior estimates. Their results showed that United States monetary shocks are responsible for significant fluctuations in Latin America, while supply and demand shocks do not. Based on their findings, they argue that "financial channel plays a crucial role in the transmission and US disturbances explain important portions of the variability of Latin American macrovariables, producing continental cyclical fluctuations and, in two episodes, destabilizing nominal exchange rate effects.

\section{Data and Methodology}

\subsection{Data}

The study uses monthly historical data from April 2004 to July 2015. The oil prices include monthly closing spot prices of the Brent (USD/barrel); monthly closing spot prices of the West Texas Intermediate Cushing (USD/barrel) and OPEC basket monthly average crude oil prices (USD/barrel), collated from bloomberg. The macroeconomic variables are real exchange rate, foreign external reserves, capital importation (which is made of 
foreign direct investment in the form of equity and other capital; foreign portfolio investment in the form of equity, bonds and money market instruments; and other investments such as trade credits, loans, currency deposits and other claims) and government revenue collated from Central Bank of Nigeria database and Ministry of Finance budget office.

\subsection{Methodology}

Extant literature on the macroeconomic effects of oil price shocks adopts four basic definitions: oil supply conditions, oil price changes, oil price volatility, and asymmetric transformations of oil price. The study adopted oil price volatility because of the use of generalized autoregressive conditional heteroskadasticity (GARCH). Nelson and Plosser (1982) was one of the seminal works that estimated the persistence in data series using business cycle theory, while Engel and Lee (1993) gave prominence to the features of stochastic process, which is the permanent and/or transitory component of volatility. In measuring whether the series of volatility are permanent or transitory, symmetric or asymmetric, scholars have used the component generalized autoregressive conditional heteroskadasticity (CGARCH), (Ibrahim \& Ahmed, 2014; Chen \& Shen, 2004), generalized autoregressive heteroscedasticity (GARCH) (Bala \& Asemota, 2013); the unit root test (Narayan \& Liu, 2011 and Shahbaz, Tiwari, Ozturk and Farooq); and asymmetric dynamic conditional correlation (Zhange \& Li, 2014).

To estimate the volatility effect of oil shock on capital importation, exchange rate, foreign external reserves and government revenue, the study adopts the Bollerslev (1986) generalized autoregressive heteroscedasticity (GARCH) model recently used by Bala and Asemota (2013) and Ibrahim and Ahmed (2014). The justification for choosing this model is three folds. First, the GARCH model has ability to distinguish between predictable and unpredictable elements in the oil shock formation process, and therefore, not prone to overstating volatility (Ogunleye, 2009). Second, a high-order ARCH model may have a more parsimonious GARCH representation that is much easier to identify and estimate (Enders, 2010, p. 131). Third, since all coefficients must be positive, it ensures that the variance is finite, and all characteristic must lie inside the unit circle (Enders, 2010, p. 131). The Bollerslev (1986) standard GARCH $(1,1)$ model is represent as:

$$
\begin{gathered}
Y_{t}=X_{t} \theta+\epsilon_{t} \\
\sigma_{t}^{2}=\omega+\alpha \varepsilon_{t-1}^{2}+\beta \sigma_{t-1}^{2}
\end{gathered}
$$

(1) is the mean equation written as function of exogenous variables with an error term. In adapting (1) to the study, crude oil price entered the model as exogenous variable while exchange rate, capital importation, government revenue and foreign capital reserves are the endogenous variables. (2) is the conditional variance equation and one-period ahead forecast based on past information. To decompose the time-varying volatility of oil price into permanent and/or transitory component, the conditional variance equation is specified as a function of the mean $(\omega)$, the ARCH term $\left(\varepsilon_{t-1}^{2}\right)$ and GARCH term $\left(\sigma_{t-1}^{2}\right)$. The persistence of $\sigma_{t-1}^{2}$ is captured by $\alpha+\beta$ and covariance stationarity requires that $\alpha+\beta \prec 1$. This is estimated using the method of maximum likelihood estimation (MLE).

To estimate the asymmetric effects between bad news (decline in oil price) and good news (increase in oil price), the study adopted the exponential GARCH model proposed by Nelson (1991). The conditional variance is:

$$
\log \left(\sigma_{t}^{2}\right)=\omega+\alpha_{1} \sum_{j=1}^{q} \beta_{j} \log \left(\sigma_{t-j}^{2}\right)+\sum_{i=1}^{n} \alpha_{i} / \frac{\mu_{t-q}}{\sigma_{t-i}} /+\sum_{k=1}^{r} y k \frac{\mu_{t-k}}{\sigma_{t-k}}
$$

When $\mu_{t-\mathrm{q}}$ is positive (good new), the total effect of $\mu_{t-\mathrm{i}}$ is $\left(1+y_{i}\right) / \mu_{t-\mathrm{i}}$. However, when $\mu_{t-\mathrm{i}}$ is negative (bad news) the total effect of $\mu_{t-\mathrm{i}}$ is $\left(1+y_{i}\right) / \mu_{t-\mathrm{i}}$. The EGARCH is covariance stationary provided $\sum_{i=1}^{n} X_{i}^{2}$

\subsection{Robustness Test}

The paper utilises a VAR model to estimate the impact of oil price shock on exchange rates, external foreign reserves, capital importation and government revenue. The aim is to evaluate the impact of crude oil shock on exchange rate, external foreign reserves, capital importation and government revenue. Specifically, the study used the generalized impulse response function and variance decomposition to examine how exchange rate, capital importation, foreign external reserves and government revenue respond to shocks by oil price shock in the VAR framework. This paper adopts the vector autoregression (VAR) framework of Johansen $(1988,1992)$, using the maximum likelihood procedure. The framework consists of four endogenous variables such as foreign exchange, foreign external reserves, capital importation and government revenue, while oil price entered the model as exogenous variable. 


\section{Discussion of Results}

\subsection{Descriptive Statistics}

Table 1. The descriptive statistics

\begin{tabular}{lccccccc}
\hline & BRENT & EXR & CIP & GOVT REVENUE & OPECBASKET & RESERVES & WTI \\
\hline Mean & 82.53029 & 150.6367 & $1.03 \mathrm{E}+09$ & 493.6921 & 92.77726 & 37856.24 & 78.14993 \\
Median & 77.76000 & 153.4800 & $8.40 \mathrm{E}+08$ & 445.0195 & 101.0500 & 38074.22 & 78.58000 \\
Maximum & 139.8300 & 222.9300 & $3.03 \mathrm{E}+09$ & 1120.132 & 122.9700 & 62081.86 & 140.0000 \\
Minimum & 34.48000 & 118.7000 & $1.02 \mathrm{E}+08$ & 196.3800 & 44.38000 & 9975.910 & 37.05000 \\
Std. Dev. & 25.66024 & 18.90965 & $6.64 \mathrm{E}+08$ & 210.1983 & 19.67077 & 11083.31 & 21.56092 \\
Skewness & 0.039838 & 0.468578 & 1.041884 & 0.705115 & -0.658492 & -0.277984 & 0.091247 \\
Kurtosis & 1.799244 & 4.256302 & 3.433737 & 2.935763 & 2.173983 & 3.342987 & 2.333037 \\
Jarque-Bera & 8.206256 & 13.20399 & 18.68713 & 11.29297 & 7.350958 & 2.400421 & 2.709480 \\
Probability & 0.016521 & 0.001358 & 0.000088 & 0.003530 & 0.025337 & 0.301131 & 0.258014 \\
Sum & 11224.12 & 19432.13 & $1.02 \mathrm{E}+11$ & 67142.13 & 6772.740 & 5110593. & 10628.39 \\
Sum Sq. Dev. & 88890.49 & 45769.57 & $4.32 \mathrm{E}+19$ & 5964750. & 27859.62 & $1.65 \mathrm{E}+10$ & 62757.90 \\
Observations & 136 & 136 & 136 & 136 & 136 & 136 & 136 \\
\hline
\end{tabular}

Table 1 presents the descriptive statistics. The descriptive results show that the average price of brent, West Texas Intermediate (WTI) and OPEC Basket Price were USD82.53, USD78.15 and USD92.77 per barrel respectively for the period under review. This result could be misleading since the bulk of the data were during the period that the oil price was above USD80 per barrel. Specifically, the price of crude oil remained consistently above USD75 per barrel between September 2008 and October 2014 before the downward in July 2014 (see figure 2 for the trend in oil prices for the period under review).

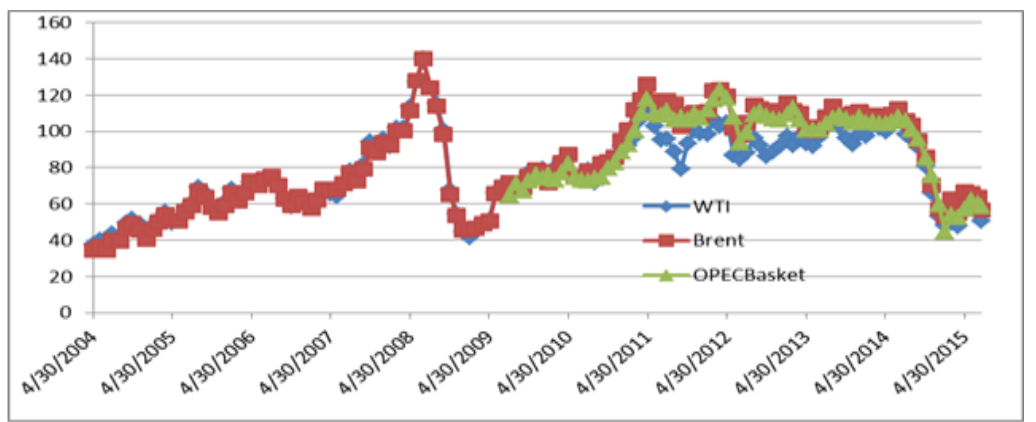

Figure 2. Oil prices trend $2004-2015$

The average value of Nigeria's foreign exchange reserves, government revenue and capital importation were USD37.9 billion, Naira493.69 billion and USD1,031,565,302 for period under review. Despite the higher average values of the variables, it is important to state that the variables have maintained steady downward trend since the declining trend in crude oil shock, as evidenced by figure 3 .

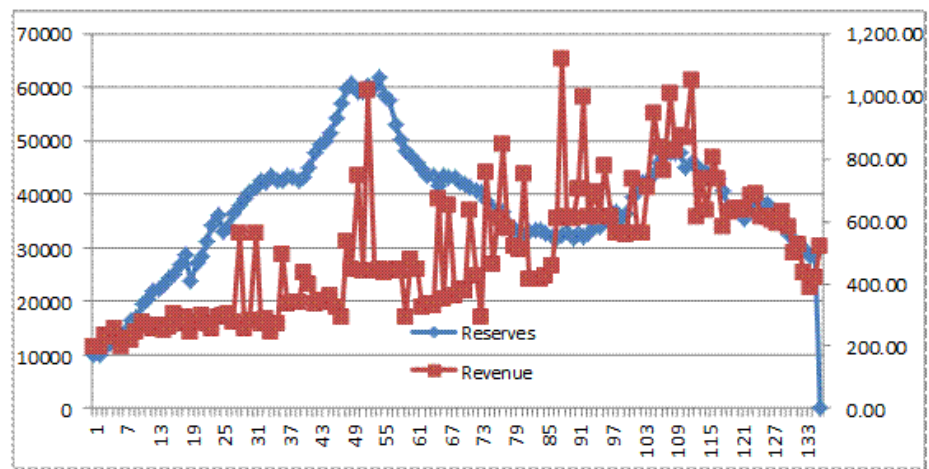

Figure 3. Trend in foreign exchange reserves and total government revenue: 2004-2015 


\subsection{Descriptive Statistics}

To determine the order of integration and ensure the stationarity of the variables used, the paper performed the Augmented Dickey-Fuller (ADF). Evidence from Table 2 indicated that all the series (CIP, EXR, CIP, Brent WTI, OPECBASKET, EFR, GOVTREV) are non-stationary at level, however, they become stationary at the first difference.

Table 2. ADF unit root results

\begin{tabular}{lccc}
\hline Variable & T-stat & Tau(probability) & Root \\
\hline CIP (Capital Importation) & -7.84236 & 0.00 & 1 \\
EXR (Exchange Rate) & -3.20392 & 0.02 & 1 \\
Brent & -3.20392 & 0.02 & 1 \\
WTI West Texas Intermediate & -5.02796 & 0.00 & 1 \\
OPECBASKET & -3.9368 & 0.00 & 1 \\
EFR (External Foreign Reserve) & -3.89931 & 0.00 & 1 \\
GOVTREV (Government Revenue & -9.05308 & 0.00 & 1 \\
\hline
\end{tabular}

\subsection{GARCH Estimation Results of Mean and Variance Equation}

Table 3 presents the results on the GARCH effect of crude oil shock on capital importation, foreign exchange reserves, government revenue and foreign exchange. The GARCH $(1,1)$ model satisfy the covariance stationary conditions that $\alpha+\beta<1$ for the three equations. This implies that the volatility persistence rates are 0.999 for brent, 0.990 for WTI and 0.8463 for OPEC basket price, which approximates unity. This means approximately $80 \%$ of the shock will remain for a long time, suggesting that the shock is persistent.

Table 3. GARCH estimation results of mean and variance equation

\begin{tabular}{llll}
\hline Variables & Brent & WTI & OPECBASKET \\
\hline C & 0.035430 & 0.072805 & 0.013214 \\
& $(0.031909)$ & $(0.062804)$ & $(0.019009)$ \\
Capital Importation & 0.22 & 0.23 & 0.09 \\
& $(0.0107)^{*}$ & $(0.0131)^{*}$ & $(0.0191)^{*}$ \\
Foreign External Reserves & 8.20 & -6.73 & -0.38 \\
& $(2.16)^{*}$ & $(1.78)$ & $(0.04)^{*}$ \\
Government Revenue & 0.087 & 0.062 & 0.33 \\
Exchange Rate & $(0.012)^{*}$ & $(0.014)^{*}$ & $(0.06)^{*}$ \\
& 0.23 & 0.509 & -0.02 \\
$\propto$ & $(0.04)^{*}$ & $(0.07)^{*}$ & $(0.01)$ \\
$\beta$ & $0.479^{*}$ & $0.463^{*}$ & $0.076585^{*}$ \\
a+b & $0.520^{*}$ & $0.527^{*}$ & $0.769749^{*}$ \\
LogL & 0.999 & 0.990 & 0.846334 \\
AIC & -97.85 & -88.25 & -97.40040 \\
SIC & 2.23 & 2.05 & 2.240008 \\
Obs & 2.44 & 2.29 & 2.481955 \\
\hline
\end{tabular}

Note. Parenthesis indicates standard error. *Significant at $5 \%$ level

This could be traced to the causes of the shock which are purely structural changes in global economy. The causes of the recent oil shock are broadly classified into demand and supply factors. The supply factors are surprise increases in oil production of the Organisation of the Petroleum Exporting Countries (see figure 4); production increases outside OPEC (production outside OPEC increase by 1.3 million barrels per day in 2013 and 2.0 million barrel per day in 2014, majorly boosted by the production of shale oil in the United States); and an unexpected shift in the OPEC supply function - the decision of members not to lower production (IMF, 2015). 


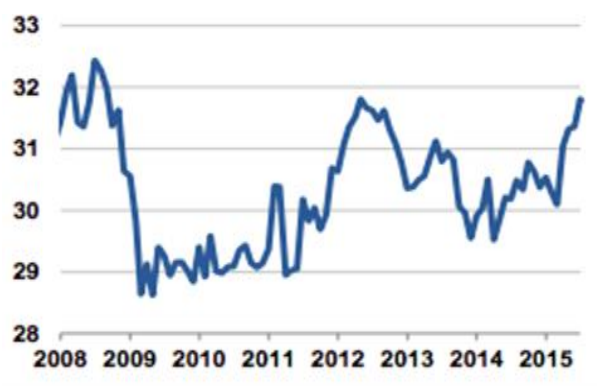

Figure 4. OPEC crude supply

Source: IEA's Oil Market Report.

The demand factor is attributed to decline in global oil consumption. For instance, global growth in oil consumption slowed significantly during 2014 to about 0.7 million per barrel (IMF, 2015). The slowdown essentially reflected technological innovations and slowdown in economic activities (see Figure 5). Primarily, the extraction of oil from shale is boosting United States (US) oil production leading to reduction of imports from other countries. Horizontal drilling and hydraulic fracturing in hydrocarbon-rich underground shale layers have increased US oil production by 65 per cent in the past five years to the highest level since 1986, and reduced crude imports by more than 3.1 million barrels a day since peaking in 2005 . This has resulted to weakness in global demand.

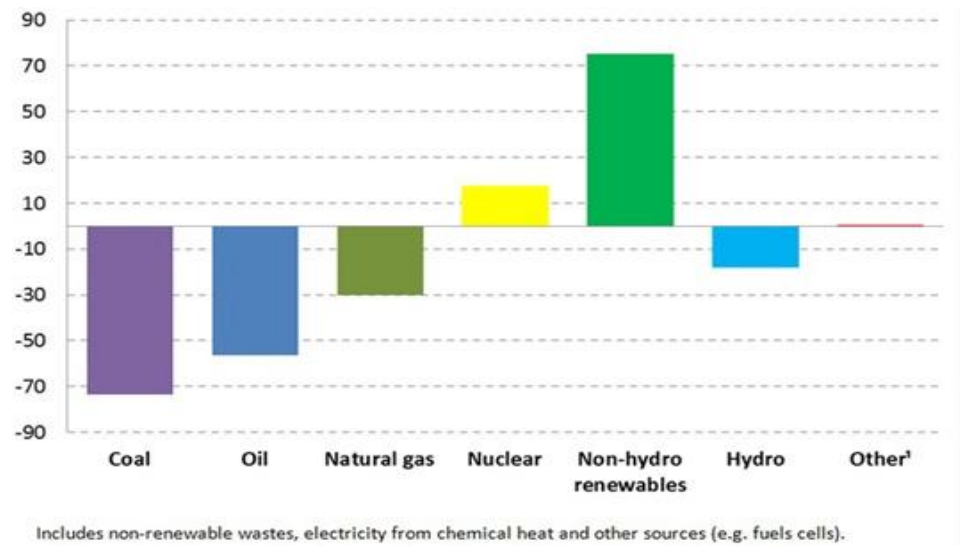

Figure 5. OECD electricity production: 2013-2014 change by source

Source: IEA's Oil Market Report.

The popularity and/or invention of alternative sources of energy, such as, solar, bio-fuel and ethanol, wind energy, nuclear binding energy, and hydrogen, is also weakening the global demand of crude oil. Finally, weakness in global economic recovery is one of the factors plunging global oil prices. For instance, slower growth in China, the world's biggest energy consumer, and the Eurozone, which has been tilting towards recession, have weakened global demand and contributed to collapse in oil prices. Thus, there is an urgent need for policy shift given the structural nature of the current shock.

The ARCH term $\propto$ and coefficients of the GARCH term are both positive and significant at $5 \%$ level, which confirms the presence of GARCH effect in the models. On the macroeconomic effect of the oil price shock, the results revealed that oil price volatility have significant positive impact on exchange rate, government revenue, foreign exchange reserves and capita importation. This means increase in oil price stimulates the Nigerian economy, while decrease in oil price retard economic activities. The results which suggest that the large variability in declining oil price is a major source of macroeconomic fluctuation, is consistent with the findings of Mordi and Adebiyi (2010), Tsai (2015), Gao, Kim, and Saba (2014), Cunado, Jo, and De Gracia (2015), Vasconez, Giraud, Isaac and Pham (2015). The result could be explained by the structure of the Nigerian economy and the transmission channels of oil price shocks to macroeconomic variables. Volatility in crude oil price is transmitted through fluctuations in oil revenue which accounts for over 80 per cent of government total revenue, external foreign reserves that has crude oil receipts as its major source, foreign portfolio inflow and naira appreciation against convertible currencies. 
The paper used the Exponential GARCH Impulse Response Function (EGIPF) to estimate whether oil positive oil price shock and negative oil price shock have equal effect on macroeconomic variables. The results show that the effect of bad news (negative shocks or decline in oil price) and good news (positive shock or increase in oil price) their covariance differs in magnitude. To address the issues of asymmetric shocks, positive shocks and negative shocks were differentiated as evidenced in Figure 5, 6, and 7. The results are not consistent with apriori expectation, but consistent with the GARCH results that estimates the macroeconomic effect of oil price shock. The responses of external foreign reserves to change in oil price do not perfectly mirror each other, which suggest that foreign external reserves responds asymmetrically to shocks in the change of oil price (See figure 5 below).

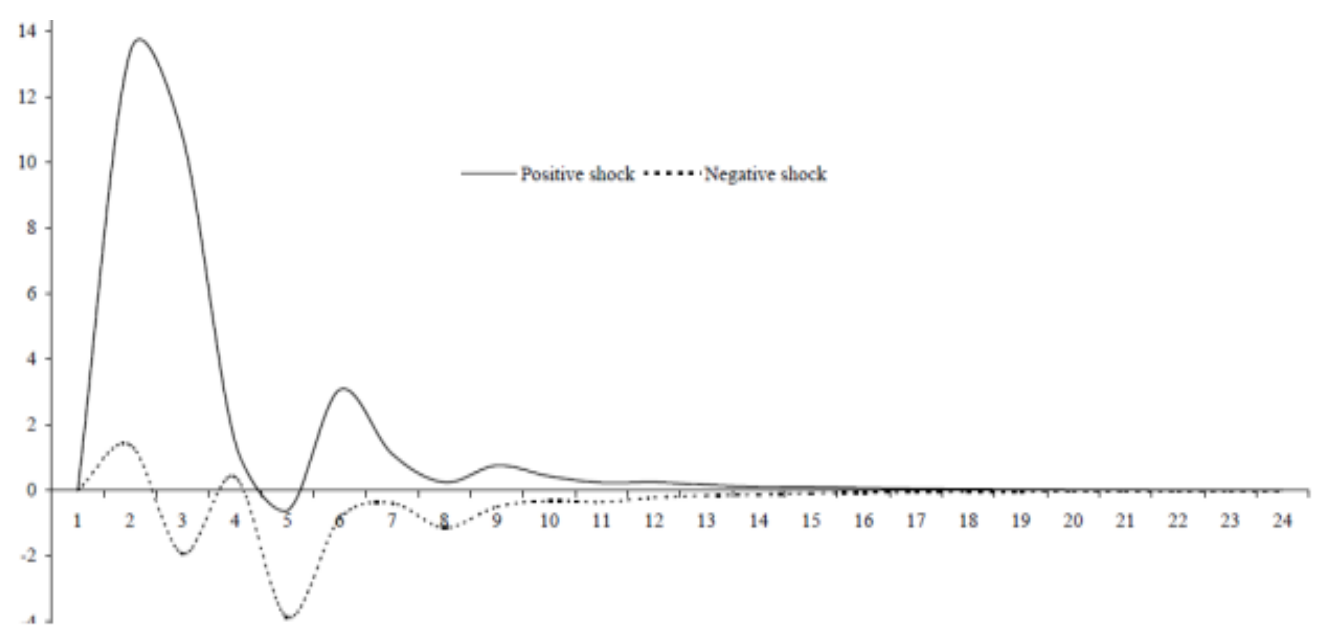

Figure 5. EGIRF of foreign external reserves to positive and negative shocks to change in oil price

Similarly, the response of revenue to oil price shock is asymmetric since the magnitude of negative is higher than positive (see table below).

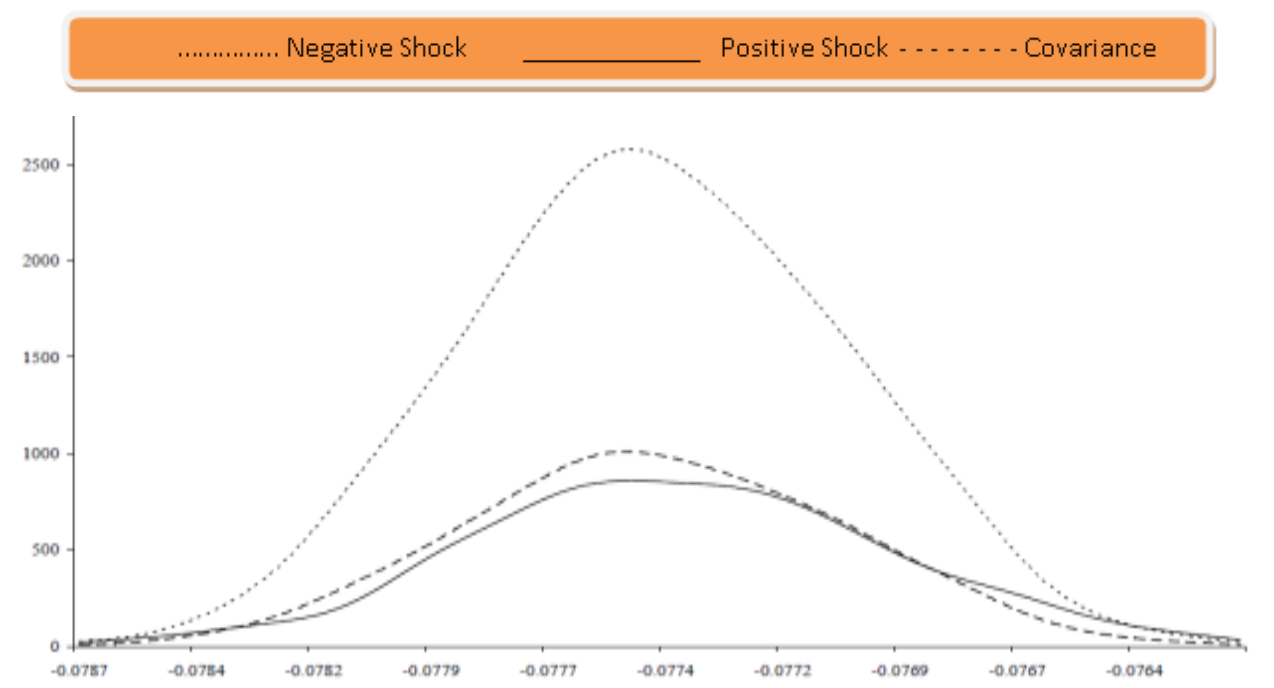

Figure 6. GIRF of total government revenue to positive and negative shocks to change in oil price

The response of Capital Importation is asymmetric and positive oil shocks return faster to zero than negative shocks which corroborates our earlier findings that the current shock is persistent (see table 7). 


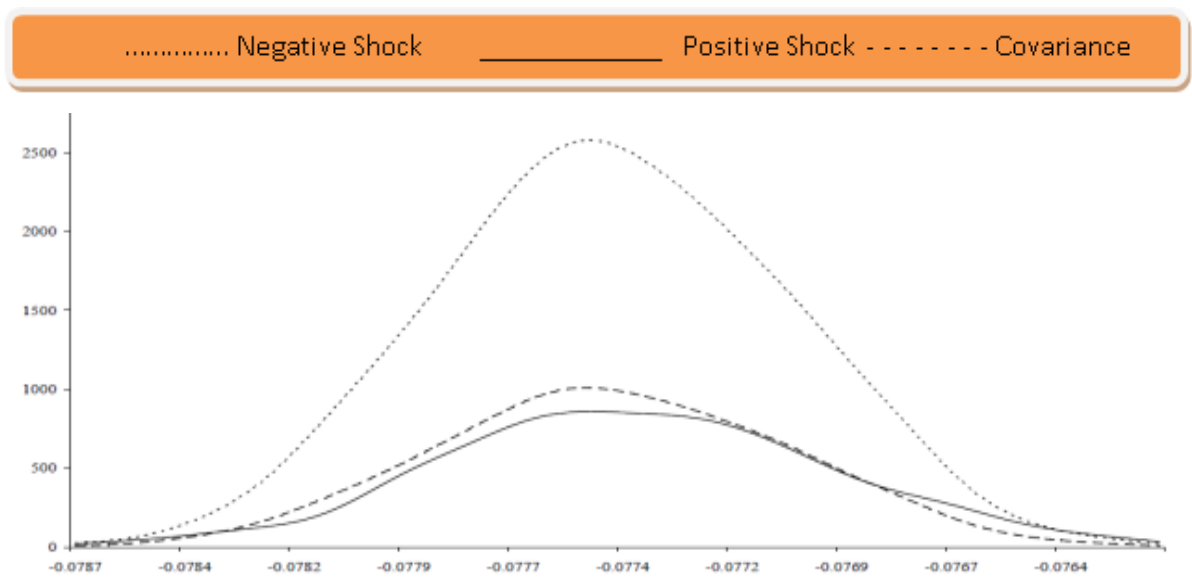

Figure 7. GIRF of capital importation to positive and negative shocks to change in oil price

\section{Policy Implications}

The results show that the current oil shock is persistent, asymmetric and impacts negatively on exchange rate, foreign exchange reserves, government revenue and capital importation. The results have strong policy implications. First, transitory shocks do not require any policy response since the effects is on the short-run, while persistent shocks requires policy action. Based on the results, there is need for policy action in order to mitigate the adverse effects of oil shocks on Nigerian macro-economy. Second, the asymmetric effects, which shows that the adverse effect of oil shocks during declining oil prices (bad news) is worse than the positive effects of oil shocks justifies the need fiscal buffers during oil boom.

\section{Suggested Areas for Further Studies}

The Use Factor Augmented Vector Autoregressive Approach (FAVA) in evaluating the asymmetric relationship between oil price shock and macroeconomic variables: Methodology applied in this area are classified into dynamic correlation of data (Hamilton, 2003); traditional approach of conducting Wald-test of the coefficients of net increase of oil price (Mordi \& Adebiyi, 2010); and the use of oil price and output-price relationship. These models assume linearity. However, recent empirical evidence use wide range of macroeconomic variables based non-linear framework such as FAVA (see An, Jin, \& Ren, 2014) and only on US economy. Such methodology could be adopted in Nigeria.

Further empirical studies could investigate the optimal threshold for the counter cyclical fiscal buffers that should be kept during positive shocks since the result has shown that the impact of negative shock on the economy is higher than positive shock.

\section{Conclusion}

This paper examines the impact of oil price shock on macroeconomic variables such as exchange rate, government revenue, capital importation and foreign exchange reserves in Nigeria. First, the results showed that the current oil price shock is persistent. Second, there is asymmetric effect between positive shock and negative shock. Third, the results revealed that oil price volatility exerts significant shock on economic activities, which could be explained by the structure - excessive dependent on oil revenue - of Nigerian economy. From a broader policy perspective, the results suggest the importance of diversifying the economy and undertaking some structural reforms such as rethinking the distribution of government revenue and developing national technology master plan. From a narrow policy perspective, the result revealed the need for policy improvement, especially, in terms of building countercyclical fiscal buffers during positive shocks to cushion the adverse effect of negative shocks.

\section{References}

Abbas, V. (2014). Dynamic Effects of Rising Oil Prices on Consumer Energy Prices in Canada and the United States: Evidence from the Last Half a Century. Energy Economies, 45, 33-44. https://doi.org/10.1016/j.eneco.2014.06.015

Allegret, J. P., Mignon, V., \& Sallenave, A. (2015). Oil Price Shocks and Global Imbalance: Lessons from a Model with Trade and Financial Interdependencies. Economic Modelling, 49, 232-247. https://doi.org/10.1016/j.econmod.2015.04.009 
An, L., Jin, X., \& Ren, X. (2014). Are the Macroeconomic Effects of oil Price Shock Symmetric? A Factor-Augmented Vector Autoregressive Approach. Energy Economics, 45, 217-228. https://doi.org/10.1016/j.eneco.2014.06.003

Bala, D. A., \& Asemota, J. (2013). Exchange-Rate Volatility in Nigeria: Application of the GARCH Model with Exogenous Break. Central Bank of Nigeria. Journal of Applied Statistics, 4(1), 89-116.

Bhattacharya, B. B., \& Kar, S. (2009). Shocks, Economic Growth and the Indian Economy. International Bank for Reconstruction and Development, Washington, D.C.

Blanchard, O. J. (2009). Why Are the 200s So Different from the 1970s? A Structural Interpretation of Changes in the Macroeconomic Effects of Oil Prices. National Bureau of Economic Research, 1050 Massachusetts Aveneue, Cambridge, MA 02138.

Bollerslev, T. (1986). Generalized Autoregressive Conditional Heteroskedasticity. Journal of Econometrics, 31(3), 307-27. https://doi.org/10.1016/0304-4076(86)90063-1

Canova, F. (2005). The Transmission of US Shocks to Latin America. Journal of Applied Econometrics, 20, 229-251. https://doi.org/10.1002/jae.837

Chen, S. W., \& Shen, C. H. (2004). GARCH, Jumps and Permanent and Transitory Components of Volatility: The Case of the Taiwan Exchange Rate. Mathematics and Computers Simulation, 67, 201-216. https://doi.org/10.1016/j.matcom.2004.06.006

Cunado, J., \& Perez, de G. (2003). Do oil price shocks matter? Evidence for some European countries. Energy Economies, 25(2), 137-154. https://doi.org/10.1016/S0140-9883(02)00099-3

Cunado, J., \& Perez, de G. (2005). Oil prices, economic activity and inflation: evidence for some Asian countries. Quarterly Review of Economics and Finance, 45(1), 65-83. https://doi.org/10.1016/j.qref.2004.02.003

Cunado, J., Jo, S., \& Gracia, F. P. (2015). Macroeconomic Impacts of Oil Price Shocks in Asian Economies. Energy Policy, forthcoming. https://doi.org/10.1016/j.enpol.2015.05.004

Dibooglu, S., \& Aleisa, E. (2004). Oil Prices, Terms of Trade Shocks, and Macroeconomic Fluctuations in Saudi Arabia. Contemporary Economic Policy, 22(1), 50-62. https://doi.org/10.1093/cep/byh005

Enders, W. (2010). Applied Econometric Time Series (3rd ed.). John Wiley and Sons: Danvers, MA.

Engle, R. F. (1982). Autoregressive Conditional Heteroskedasticity with Estimates of the Variance of United Kingdom Inflation. Econometrica, 50(4), 987-1007. https://doi.org/10.2307/1912773

Fedredere, P. J. (1996). Oil Price Volatility and the Macroeconomy. Journal of Macroeconomics, 18(1), 1-26. https://doi.org/10.1016/S0164-0704(96)80001-2

Hamilton, D. J. (2009). Causes and Consequences of the Oil Shocks of 2007-2008.

Hill, C. R., Griffiths, W. E., \& Lim, G. C. (2008). Principles of Econometrics. John Wiley and Sons: Danvers, MA.

Ibrahim, H. M., \& Ahmed, H. J. A. (2014). Permanent and Transitory Oil Volatility and Aggregate Investment in Malaysia. Energy Policy, 67, 552-563. https://doi.org/10.1016/j.enpol.2013.11.072

IMF. (2003). Fund Assistance for Countries Facing Exogenous Shocks. Policy Development and Review Department, International Monetary Fund.

IMF. (2015). World Economic and Financial Surveys: World Economic Outlook (April 2015). Washington, DC 20090.

Jimenez-Rodrigues, R., \& Sanchez, M. (2005). Oil Price Shocks and the Real GDP: Empirical Evidence for Some OECD Countries. Applied $\quad$ Economics, 37(2), 201-228. https://doi.org/10.1080/0003684042000281561

Jin, X. (2015). Volatility Transmission and Volatility Impulse Response Functions Among the Greater China Stock Markets. Journal of Asian Economies, 39, 43-58. https://doi.org/10.1016/j.asieco.2015.05.004

Kilian, L. (2008). Exogenous Shocks: How Big Are They and How Much Do They Matter for US Economy. Review of Economics and Statistics, 90(2), 216-240. https://doi.org/10.1162/rest.90.2.216

Kose, M. A., \& Riesmanb, R. (2001). Trade Shocks and Macroeconomic Fluctuations in Africa. Journal of Development Economics, 65(1), 55-80. https://doi.org/10.1016/S0304-3878(01)00127-4

Lilien, D. (1982). Sectoral Shifts and Cyclical Unemployment. Journal of Political Economy, 90, 777-793. 
https://doi.org/10.1086/261088

Mehara, M. (2006). Energy Consumption and Economic Growth: The Case of Oil Exporting Countries. Energy Policy, 35(5), 2939-2945. https://doi.org/10.1016/j.enpol.2006.10.018

Narayan, P. K., \& Liu, R. (2011). Are Shocks to Commodity Prices Persistent? Applied Energy, 88(1), 409-416. https://doi.org/10.1016/j.apenergy.2010.07.032

Nazlioglu, S., Soytas, U., \& Gupta, R. (2015). Oil Prices and Financial Stress: A Volatility Spillover Analysis. Energy Policy, 82, 278-288. https://doi.org/10.1016/j.enpol.2015.01.003

Ncube, M., Ndou, E., \& Gumata, N. (2012). How are the US Financial Shocks Transmitted into South Africa? Structural VAR Evidence. African Development Bank Group Working Paper Series No. 157.

Nelson, C., \& Plosser, C. (1982). Trends and random walks in macroeconmic time series: Some evidence and $\begin{array}{lllll}\text { implications. Journal of Monetary } & \text { Economics, } & \text { 10(2), }\end{array}$ https://doi.org/10.1016/0304-3932(82)90012-5

Ogunleye, E. K. (2009). Exchange Rate Volatility and Foreign Direct Investment in Sub-Saharan Africa: Evidence from Nigeria and South Africa. Paper Presented at Centre for Study of African Economies, Oxford.

Raddatz, C. (2007). Are External Shocks Responsible for the Instability of Output in Low-Income Countries? Journal of Development Economics, 84(1), 155-187. https://doi.org/10.1016/j.jdeveco.2006.11.001

Shahbaz, M., Tiwari, K. A., Ozturk, I., \& Farooq, A. (2013). Are Fluctuations in Electricity Consumption Per Capita Transitory? Evidence from Developed and Developing Economies. Renewable and Sustainable Energy Reviews, 28, 551-554. https://doi.org/10.1016/j.rser.2013.08.007

Sosa, S., \& Adler, G. (2012). Intra-Regional Spillovers in South America: Is Brazil Systemic after All? IMF Working Paper WP/12/145 (Washington: International Monetary Fund).

UNCTAD Least Developed Countries Report. (2002). Escaping the Poverty Trap. United Nations Conference on Trade and Development.

Vasconez, V. A., Giraud, G., Isaac, F. M., \& Pham, N. (2015). The Effects of Oil Price Shocks in a New-Keynesian Framework with Capital Accumulation. Energy Policy, forthcoming.

World Bank Global Monitoring Report. (2004). Policies and Actions for Achieving the Millenium Development goals and Related Outcomes. International Bank for Reconstruction and Development, Washington, D.C.

World Development Report. (2000). Attacking Poverty. New York: Oxford University Press.

Yuan, Y., Zhaung, X., Liu, Z., \& Huang, W. (2014). Analysis of the Temporal Properties of Price Shock Sequences in Crude Oil Markets. Physica A, 394, 235-24. https://doi.org/10.1016/j.physa.2013.09.040

Zhang, B., \& Li, X. (2014). Recent Hikes in Oil-Equity Market Correlations: Transitory or Permanent? Energy Economies, forthcoming.

\section{Copyrights}

Copyright for this article is retained by the author(s), with first publication rights granted to the journal.

This is an open-access article distributed under the terms and conditions of the Creative Commons Attribution license (http://creativecommons.org/licenses/by/4.0/). 